\title{
Exploring and Analyzing the Path of Incorporating Women's Views in the New Era Into the Course of "Ideological and Moral Cultivation and Legal Basis"
}

\author{
Zeng Mingfang $^{1 *}$ \\ ${ }^{1}$ Department Ideological and Political Education, The Modern College of Northwest University, Xi'an, Shaanxi, \\ China \\ *Email: zengmingfang2021@163.com
}

\begin{abstract}
Since the 18th CPC National Congress, guided by Xi Jinping Thought on Socialism with Chinese Characteristics for a New Era, there has been a firmer belief in the future of women development based on Chinese socialism among Chinese women. In this background, women are able to participate in economic and social development, play a unique role in the construction of family civilization, pursue gender equality. As masters of the nation, women now can find the best ways to fulfill themselves, as witnessed by the historic accomplishments they've made so far. "Ideological and moral cultivation and legal Basis" is one of the compulsory ideological and political theory courses for college students stipulated by the Propaganda Department of the CPC Central Committee and the Ministry of education. It undertakes the task of cultivating students' basic quality of being a man. It is an ideological and political theory course with the goal of improving students' self-cultivation and comprehensive quality. The integration of women's views in the new era into "Ideological and moral cultivation and legal Basis" can make the teaching content more in line with the students' reality, and constantly improve the affinity and pertinence of Ideological and political education. It is of great significance to cultivate students' correct gender thinking and promote the free and comprehensive development of female college students.Starting from the teaching content of the chapters, this article explores an effective path and combines the teaching material system with the teaching system, which really makes this course engrossed for students, and guides college students to better grow into newcomers of the era who consciously assume the responsibility of national rejuvenation.
\end{abstract}

Keywords: Women's views, Ideological and Moral Cultivation and Legal Basis, Path

\section{INTRODUCTION}

Since the 18th CPC National Congress, China has attached great importance to and actively promoted the development of women's cause, and insisted on advancing the "people-oriented" ruling philosophy, which has made women's status in social and economic development increasingly prominent, their level of education continuously improved, and their role in the construction of family civilization Unique role, etc., women's cause in the new era has achieved worldrenowned achievements. "Ideological and moral cultivation and legal Basis" (hereinafter referred to as "Basis" course) is an ideological and political theory course integrating ideology, politics, science, theory and practice. This course aims at the ideological, moral and legal issues faced by universities in the process of growing up, and develops Marxist world outlook, life outlook, values, ethics, and rule of law education to guide college students to improve their ideological and moral qualities and the rule of law, and grow into a conscious responsibility for national rejuvenation Newcomers of the era. ${ }^{[1]}$ "Basis" course is a course about the value orientation of college students, which focuses on the daily behavior of college students, and carries out education on the ideological and moral and comprehensive quality of college students, which contains a profound theme of human nature education. 
China attaches great importance to the development of women's cause in the new era, and the educational goal of the "Basis" course is consistent with the "peopleoriented" concept. Therefore, it is feasible and meaningful to integrate the new era women's views into the "Basis" course. Therefore, this article grasps the basic content of women's views in the new era from the perspectives of women's status in economic and social development, the unique role of family civilization construction, and the pursuit of gender equality, and discusses the significance of its integration into "Basis" course. From the teaching content of the textbook chapters set out to explore the specific path of integrating women's views in the new era into the teaching of "Basis" course.

\section{THE BASIC CONTENT OF WOMEN'S VIEWS IN THE NEW ERA}

The new era is the key word for us to understand the current historical position. In the report of the 19th CPC National Congress, General Secretary Xi Jinping solemnly declared, "With decades of hard work, socialism with Chinese characteristics has crossed the threshold into a new era. This is a new historic juncture in China's development." "The Chinese nation, which since modern times began had endured so much for so long, has achieved a tremendous transformation: it has stood up, grown rich, and is becoming strong; it has come to embrace the brilliant prospects of rejuvenation." [2] This shows that socialism with Chinese characteristics has ushered in a new historic leap. It also means that women's cause has made historic achievements and that the status of women has undergone earth-shaking changes. In the new era of socialism with Chinese characteristics, women must not only actively embrace various opportunities, but also have the courage to face difficulties, accept challenges, and achieve their brilliant lives. China has entered a new era. The Central Committee of the Communist Party of China attaches great importance to women's work, puts forward a series of new requirements and deployments, creates a good atmosphere of respect and care for women in the whole society, and has achieved good results. At the same time, the majority of women set up the spirit of self-esteem, self-confidence, self-reliance and self-improvement, and formed a good atmosphere of patriotism and dedication, honesty and friendliness, dedication, thrift and good attitude.

\subsection{WOMEN'S SUBJECT CONSCIOUSNESS AND ABILITY IN ECONOMIC AND SOCIAL DEVELOPMENT HAVE INCREASED SIGNIFICANTLY}

Women are an important force in promoting social development. Marx pointed out that, "Everyone who knows a bit of history also knows that there can be no great social changes without women's enzymes. The progress of society can be accurately measured by the social status of women (including the ugly ones)." General Secretary Xi Jinping emphasized at the Global Summit of Woman in September 2015, "Women are the creators of material civilization and spiritual civilization, and they are an important force to promote social development and progress. Without women, there would be no human beings and no society." ${ }^{[3]}$ Social history is created by the people. With the development of society, women in the new era have created a rich and colorful social history while pursuing their own liberation, and their status in social development has become increasingly prominent. At the same time, in the process of promoting the modernization of national governance system and governance capacity, women's subject consciousness has been increasingly strengthened, and they have made great contributions in poverty alleviation, rural revitalization, innovation and entrepreneurship, democratic political construction, grass-roots governance, epidemic prevention and control, international cooperation and exchange, etc. Women's ability to participate in economic and social development has also been significantly enhanced. They have demonstrated the role of talent as the first resource in the socialist modernization drive, and they have demonstrated their feminine demeanor in various fields such as politics, economy, science and technology, culture, and health. For example, Nobel Prize winner $\mathrm{Tu}$ Youyou has made outstanding contributions to the research of traditional Chinese medicine and the combination of Chinese and Western medicine, and is an outstanding representative of Chinese women.

\subsection{WOMEN PLAY A UNIQUE ROLE IN THE CONSTRUCTION OF FAMILY CIVILIZATION}

Chinese traditional culture puts forward the idea of "self-cultivation, regulating the family, governing the country and balancing the world". It regards "regulating the family" as the basis of "governing the country" and regards family as the foundation of maintaining social development. As the basic cell of society, family regards the fate of individual, family and country as a whole. As a member of the family, it is particularly important for women to mobilize them to participate in the construction of family civilization. The current family relationships are mainly intergenerational relationships, husband and wife relationships, and children relationships. In these relationships, women play a unique role. The majority of women should maintain the harmony and stability of the family, be the inheritors of the building of a good family style, and also pay attention to their own words and deeds, be important guides in family education, and form a kind of "patriotism, love for each other, love for others, building and sharing a new style of socialist family civilization." ${ }^{[4]}$ 


\subsection{PURSUING EQUALITY BETWEEN MEN AND WOMEN}

Gender equality is China's basic national policy. Since the 18th National Congress of the Communist Party of China, the country has successively introduced laws and regulations to promote equality between men and women, vigorously promote the ideas of men and women, and promote the development of women's cause. Women's enthusiasm for practicing gender equality and achieving gender harmony has increased. In the new era, women's attention to public affairs is constantly increasing, and the proportion of receiving higher education and participating in business management are steadily increasing. Obviously, they have played the role of talent as the first resource. The 13th session of the NPC has 742 female delegates, accounting for $24.9 \%$ of the total, and an increase of 1.5 percentage points from the previous session.", "In 2018, the number of female graduate students in higher education was 1.36 million, accounting for $49.6 \%$ of all graduate students, and an increase of 1.8 percentage points compared with 2010 . There were 14.87 million female students in colleges and universities, accounting for $52.5 \%$, and an increase of 1.6 percentage points from 2010. There were 3.51 million female students in adult programs of colleges and universities, accounting for $59.4 \%$, an increase of 6.2 percentage points from 2010. "[5] The increase in the number of women's congresses and female college students reflects the improvement of Chinese women's education and gender equality. Intellectual women in the new era have received good education and pave the way for their own development. They are the backbone of the modernization of the national governance system and governance capabilities.

\section{IMPORTANCE OF INTEGRATING WOMEN'S VIEWS IN THE NEW ERA INTO "BASIS" COURSE}

The integration of women's views into the "Basis" course in the new era takes the outlook on life, ideals and beliefs, moral education, career choice, marriage and love in the course content as the breakthrough point. The teaching content of the "Basis" course can not only solve the confusion of current life, but also strengthen the understanding of entering the society in the future and lay a foundation for mastering life, making it more suitable for students' reality, and then strengthen the classroom teaching results. Therefore, it is of great significance to integrate women's views into the "Basis" course in the new era.

\subsection{CONDUCIVE TO ENHANCING THE AFFINITY AND PERTINENCE OF IDEOLOGICAL AND POLITICAL EDUCATION}

General Secretary Xi Jinping emphasized at the National University Ideological and Political Work Conference to enhance the affinity and pertinence of ideological and political education to meet the needs and expectations of students' growth and development. Ideological and political work must adapt to the new situation and strive to solve new problems. Therefore, in making good use of the main channel of Ideological and political classroom, teachers of Ideological and political theory course need to explore new teaching methods, promote teaching reform, and earnestly focus on students, care for students, and serve students. For example, when teaching the concept of love and marriage of college students, the teachers of Ideological and political education in Colleges can combine the content and concept of current college students' Ideological and political education, fully integrate the women's views of the new era in the "Basis" course, discuss the love and marriage problems pertinently, and publicize the common sense of law in combination with the hot topics on the Internet, such as surrogacy, domestic violence, sexual harassment and so on, so as to fundamentally promote the development of college students special care and guidance education.

\subsection{HELP TO CULTIVATE CORRECT GENDER THINKING}

In the 19th report of the Communist Party of China, it was clearly pointed out that "we must adhere to the basic national policy of equality between men and women and protect the legitimate rights and interests of women and children." China has also issued relevant policies, laws and regulations to promote gender equality, vigorously promote the idea of gender equality, and actively promote gender education. Therefore, by incorporating women's views in the new era into the "Basis" course, conducting gender education for college students, and understanding society from a new perspective, students can fully realize the importance of looking at problems from a gender perspective and cultivate their correct gender thinking. For example, for employers who often require "male only" and "male priority" when recruiting employees, even if female employees are recruited, they often require unreasonable requirements such as "not getting married within 3 years" and "not being a mother". Women can adopt equal employment rights, the implementation of equal pay for men and women for equal work, elimination of gender discrimination in employment and other related theories on gender equality communicate with employers to increase the success rate of job applications. Incorporating women's views in the new era into the "Basis" course and cultivating students' gender 
thinking can transform college students' cognitive style, improve their cognitive level, eliminate gender discrimination, and promote the idea of equality between men and women.

\subsection{PROMOTE THE FREE AND ALL- ROUND DEVELOPMENT OF FEMALE COLLEGE STUDENTS}

Men and women share a world, develop together, eliminate prejudice and discrimination against women, and the pace of social progress can be accelerated. At present, the majority of women actively participate in economic and social development and family construction, and have been highly recognized by society and families. Incorporate new-age women's views into the "Basis" course, and systematically educate students, especially female students, through relevant women's theories. College students have more initiative in personal development, can achieve independence in economic and ideological aspects, and rely on themselves. Their efforts to realize the value of life will promote their free and comprehensive development.

\section{EXPLORING AND ANALYZING THE PATH OF INCORPORATING WOMEN'S VIEWS IN THE NEW ERA INTO THE "BASIS" COURSE}

In the process of transforming "Basis" course from the teaching material system to the teaching system, college ideological and political teachers should grasp the teaching materials, optimize teaching content, innovate teaching methods, and enhance teaching timeliness. The details are as follows:

The first chapter of "Basis" course is "the question of youth in life", which mainly explores the question of outlook on life and values. This chapter can be well integrated into women's views in the new era. The current society, especially the rapid development of the selfmedia, is affected by various thoughts and concepts at home and abroad. There are various misconceptions such as money worship, consumerism, and hedonism in the society. These concepts are also spreading on college campuses. For example, "Reading is useless", "A good job is worse than a good marriage", "I would rather cry in a BMW than laugh on a bicycle", etc. Some female college students are affected by this, and their ideas are not stable. The focus on high consumption and too much attention to appearance leads to a waste of studies. Therefore, according to the content of the chapter, it is necessary to incorporate systematic new-age women's views in the third section "Creating a meaningful life". In practical teaching, students can be arranged to list typical cases of outstanding female medical staff or female volunteers who have made outstanding contributions in the epidemic according to the new coronavirus pneumonia epidemic in China in 2020, and let students talk about their own sentiment. This epidemic, everyone has too much thinking and perception, about pay, responsibility, life, the relation- ship between human and nature and so on. Therefore, we can carry out social responsibility education, gratitude education and outlook on life education for students, and praise the power of women. Through this kind of case teaching, we can help college students establish a correct outlook on life, become self-esteem, self-confidence, self-reliance and self- improvement college students in the new era, and create a meaningful life.

The second chapter of the "Basis" course is "Strengthening Ideals and Beliefs". The main content of this chapter is about ideal and belief education. One of the teaching focuses in this chapter is the relationship between ideals and reality. This focus appears in the third section "Flying Youth Dreams in the Practice of Realizing the Chinese Dream". The 85-year-old Nobel Prize winner $\mathrm{Tu}$ Youyou can be interspersed in the teaching process. The touching deeds of "a grass changes the world" help students understand the relationship between ideals and reality, and realize that the realization of ideals is often an arduous process. The greater the ideal, the more complicated the process of realization will be. The spirit of perseverance and hard work is implemented in daily study, life and work, and college students are encouraged to be fighters who dare to pursue their dreams.

The third chapter of the "Basis" course is "Promoting the Chinese Spirit." Emphasis on the spirit is an excellent tradition of the Chinese nation. From ancient times to today, there have been many great women in Chinese history, such as Hua Mulan in the story of "Hua Mulan joins the army for her father". She was sincere to the country, filial to her parents, and Soong Ching Ling, who was willing to serve the country and the people and dedicated herself, Tu Youyou and so on. It can also be learnt from the touching stories of female medical staff or female volunteers who have made outstanding contributions to the new coronavirus pneumonia epidemic in China in the first chapter mentioned in this paper. They show great and rich China spirit in the fight against epidemic diseases. In addition, it is also possible to intersperse the "spirit of women's volleyball", the representative of the era. The Chinese women's volleyball team fought tenaciously and bravely in the world volleyball matches, winning five consecutive world championships, winning glory for the country and making contributions to the people. In different periods, the majority of women have made immortal contributions to the country and society. They have embodied the virtues of loving the motherland, unity and mutual assistance, courage to take responsibility, and hard work. According to the teaching content, students can be arranged before class to sort out relevant materials about great women in Chinese history and give lectures in class. For college students in the new era, these typical cases 
can help them better understand the relationship between individuals and the country, and inspire college students to inherit the fine tradition of Chinese national patriotism and consciously be loyal patriots in the new era.

The fifth chapter of the "Basis" course "Brightness, obedience to public morality, and strict private morality" involved the traditional Chinese virtues, Chinese revolutionary morality and socialist morality. When carrying out moral education for college students, we should follow the attitude of taking the essence of them, and inherit the essence of traditional culture, and give play to the educational function of traditional virtues, so that traditional virtues can blend in with students' daily life, produce the function of educating people, and enrich the spiritual world of students. In the process of teaching, through case analysis, the traditional virtues of Chinese women are deeply explored and expounded. For example, Mengmu, who is known as "the mother teachs one person", is a great mother. In order to correctly educate her child, she has played a vital role in the cultivation of Mencius. He Zehui, the first generation of nuclear physicist in China, known as "Mrs. Curie of China," she rigorously pursues academic studies, seeks the truth, is full of patriotism, and does not seek return.

\section{CONCLUSION}

In the long-term historical development, Chinese women have formed the virtues of loving the country, being thrifty and keeping the house, bearing hardships and standing hard work, and constantly striving for selfimprovement. They have a unique position in family, family education, family style construction, and social and economic construction. Therefore, by integrating women's views in the new era into the "Basis" course, college students will be able to focus on ethical practice on the basis of theoretical and practical learning, and inherit Chinese traditional virtues and excellent women's virtues; They observe civic ethics, pay attention to family life and social practice, deepen their understanding of family, occupation and society, and establish correct Morality, family, marriage, and employment will prepare the mind for a unique role in family construction in the future, and lay a solid foundation for cultivating good professional ethics and employment psychology in the future.

\section{REFERENCES}

[1] Shen, Z.H. (2018) Introduction. In: YuHui, Y. (Eds.), Ideologicaland Moral Cultivation and Legal Basis. Higher Education Press, Beijing. pp. 7.

[2] Xi Jinping People's Daily. (2017) Secure a Decisive Victory in Building a Moderately Prosperous Society in All Respects and Strive for the Great Success of Socialism with Chinese Characteristics for a New Era-Delivered at the 19th National
Congress of the Communist Party of China. http://cpc.people.com.cn/19th/n1/2017/1027/c4143 95-29613458.html.

[3] Xi Jinping People's Daily. (2015) Xi Jinping's speech at the Global Women's Summit. http://world.people.com.cn/n/2015/0928/c100227641404.html.

[4] The State Council Information Office of the People's Republic of China People's Daily. (2019) Equality, Development and Sharing: Progress of Women's Cause in 70 Years Since New China's Founding. http://politics.people.com.cn/n1/2019/0919/c1001 31362781.html.

[5] The National Bureau of Statistics of China National Bureau of Statistics. (2019) 2018 Statistical Monitoring Report on the Implementation of China National Program for women's Development (20112020).http://www.stats.gov.cn/tjsj/zxfb/201912/t20 191206_1715998.html 